\title{
Correction: Sex and gender considerations in health research: a trainee and allied research personnel perspective
}

\author{
C. Z. Kalenga, J. Parsons Leigh, J. Griffith, D. C. Wolf, S. M. Dumanski, A. Desjarlais, L. Petermann \& \\ S. B. Ahmed (1)
}

Correction to: Humanities and Social Sciences Communications https://doi.org/10.1057/s41599-020-00643-3, published online 16 November 2020.

The article has been corrected to include a missing Acknowledgement of funding.

The paper now includes this statement:

Published online: 24 February 2022

\section{Acknowledgements}

This work was supported in part by the Canadian Institutes of Health Research Institute of Gender and Health and the Libin Cardiovascular Institute, University of Calgary.

\footnotetext{
(c) (i) Open Access This article is licensed under a Creative Commons Attribution 4.0 International License, which permits use, sharing, adaptation, distribution and reproduction in any medium or format, as long as you give appropriate credit to the original author(s) and the source, provide a link to the Creative Commons license, and indicate if changes were made. The images or other third party material in this article are included in the article's Creative Commons license, unless indicated otherwise in a credit line to the material. If material is not included in the article's Creative Commons license and your intended use is not permitted by statutory regulation or exceeds the permitted use, you will need to obtain permission directly from the copyright holder. To view a copy of this license, visit http://creativecommons.org/licenses/by/4.0/.
}

(C) The Author(s) 2022 